\title{
Political Trust, Corruption and Ratings of the IMF and the World Bank
}

\author{
Michael Breen \\ Dublin City University \\ and \\ Robert Gillanders \\ Aalto University and HECER
}

Discussion Paper No. 374

November 2013

ISSN 1795-0562

HECER - Helsinki Center of Economic Research, P.O. Box 17 (Arkadiankatu 7), FI-00014 University of Helsinki, FINLAND, Tel +358-9-191-28780, Fax +358-9-191-28781, E-mail info-hecer@helsinki.fi, Internet www.hecer.fi 


\title{
Political Trust, Corruption and Ratings of the IMF and the World Bank
}

\begin{abstract}
There are only a handful of studies that examine public support for the IMF and World Bank. At the individual level, evaluations of the economy feature prominently in these studies. Utilizing data from the Afrobarometer study, we find that evaluations of the economy, ideology and a range of socio-demographic factors including age, gender, employment status, health, education, and living conditions are not significantly related to ratings of effectiveness. Rather, we find that political trust and corruption - two very important concepts in the wider literature on individual level attitudes toward international relations and foreign policy issues - are strongly associated with ratings of effectiveness.
\end{abstract}

JEL Classification: F53, F5, F6, F60, P16

Keywords: IMF, World Bank, public opinion

Michael Breen

Centre for International Studies

School of Law and Government

Dublin City University

Dublin 9

IRELAND

e-mail: michael.breen@dcu.ie
Robert Gillanders

Department of Economics

School of Business

Aalto University

P.O. Box 21240

FI-00076 AALTO

FINLAND

e-mail: rgillanders@gmail.com 


\section{Introduction}

The International Monetary Fund (IMF) and the World Bank are two of the most important international organizations in modern times. Only a handful of developing countries have not participated in an IMF or World Bank program, and this list grows smaller every year. As a consequence, scholars from across the social sciences have been engaged in explaining the effect of IMF and World Bank programs on a diverse range of outcomes in development, education, health, conflict, economics and government policy. But despite being the subject of considerable research in all of these areas, we know very little about whether citizens in developing countries, some of which face grave problems, believe that international economic organizations (IEOs) are working effectively. Public opinion research can help to shed light on this question and, even more importantly, it can help us to understand the reasons why some citizens think international organizations work, while others believe that they are failing to deliver.

There are only a handful of studies on the determinants of attitudes toward international economic organizations. Evaluations of the economy, a staple of public opinion research, feature prominently in these studies. It is not surprising that the economy should be a key focal point in the literature. The IMF and the World Bank are perhaps the most influential and visible international organizations in modern times. Both organizations possess the ability to impose change from the outside, monitor policy implementation and enforce compliance. Few international organizations have the same breath of influence and level of input into national policy making. Their ability to impose conditions in return for financial support has been a source of great controversy, with critics accusing them of undermining national sovereignty. Citizens that live in developing countries may fear the actual or potential distributional effects of an IMF or World Bank programs. ${ }^{1}$ This is quite plausible because previous work has demonstrated that governments sometimes use IMF programs to push through unpopular economic reforms (Vreeland 2003). Moreover, there is a substantial literature which has been resoundingly negative about the impact of structural adjustment in developing countries (Woods 2006; Collier and Gunning

\footnotetext{
${ }^{1}$ For example, they may draw a link between entering into an IMF program and harsh spending cuts.
} 
1999; Crisp and Kelly 1999; Noorbakhsh and Paloni 2001; Easterly 2005; Abouharb and Cingranelli 2006).

This study's empirical focus is sub-Saharan Africa, where the IMF and World Bank have been highly active since the 1970s. Surprisingly, we find that evaluations of the economy, ideology and a range of socio-demographic factors including age, gender, employment status, health, education, and living conditions are not important determinants of ratings of effectiveness. Rather, we find that attitudes toward the IMF and World Bank are a product of an individual's relation to the state. The greater an individual's trust in domestic public institutions, the more highly they rate the performance of the IMF and the World Bank. Similarly, when an individual participates actively in civil society, we find that they tend to rate both organizations more favourably. When an individual has experienced corruption, however, they tend to award lower ratings. Taken together, our findings suggest an individual's relationship to the state and authority, whether good or bad, trumps a range of other factors.

The paper is organised as follows. First, we consider the role of the IMF and the World Bank in sub-Saharan Africa and the extent of public support for both organizations in the region. Second, we place our work in the context of the existing literature on attitudes toward international economic organizations and show how this literature can be extended to incorporate political trust and corruption. Third, we present our methods, data and findings. The final section concludes with a discussion of the relevance of our findings to the wider literature on international organizations, development and globalization.

\section{The IMF and the World Bank in sub-Saharan Africa}

In the 1970s many sub-Saharan African states came to rely heavily on the IMF and the World Bank (Woods 2006:141). Since this time, both organizations have assumed a prominent role in economic policymaking through regular consultations, technical support, and short and long-term adjustment programs. Their work in the region has often resulted in them becoming highly visible in everyday politics. A good example of this comes from Nigeria. During the 1980s, President Major General Ibrahim Babangida 'invited the entire country to participate in what he called a "town 
meeting" on the IMF. The New York Times reported that "Day after day on dusty street corners, in tiny shops and air conditioned offices, people are arguing, waving fists and shouting about the International Monetary Fund.' (Vreeland 2007:60-61). Today, both organizations are still heavily involved in economic policymaking in the region. The majority of the loans disbursed under the IMF's concessional lending arrangements go to African states. In fact, the average stint of participation in an IMF arrangement is about five years and some critics have argued that participation has led to continued dependence on IMF and World Bank resources. ${ }^{2}$ The most extreme examples of 'recidivism' within the context of sub-Saharan Africa are Mali, which spent 19 years from 1991-2000 in an IMF arrangement, Zaire, which spent 13 years from 1976-89, and Liberia, which spent 15 years from 1963-1977 (Vreeland 2007:30). However, some states in the region have had very little contact. For example, Angola didn't borrow from the IMF until 2009 and Botswana, Eritrea, Namibia, and Swaziland have never borrowed. ${ }^{3}$

Africa is even more important to the World Bank. Not only is the largest part of its organizational complex dedicated to Africa, but many within the Bank recognise that the future of global development efforts depends critically on how World Bank programs in Africa perform (Marshall 2008:47). There is also substantial variation in World Bank support across the region. There are currently 212 active projects in Tanzania amounting to USD9.95 billion - a similar number to Nigeria where there are 162 projects worth USD16.2 billion for a population that is 3.5 times larger. Moreover, some countries have had relatively little support from the World Bank: as of 2013 there are only 2 ongoing projects in Namibia amounting to USD0.02 billion and in three of the last ten years there have been no active projects. Recent work has found glaring weaknesses in the way in which support has been delivered in subSaharan Africa. Winters (2010), for example, has found that the World Bank tends to grant less autonomy to IDA-eligible states with higher levels of good governance, even though the opposite should prevail. ${ }^{4}$ In addition, Stone (2004) has found that IMF programs in Africa have lacked credibility because donor countries, especially

\footnotetext{
${ }^{2}$ The figure of 5 years comes from Vreeland (2007). For a discussion of 'recidivism' in IMF lending see Conway (2007) and Bird et al. (2004).

${ }^{3}$ While some of these states have used IMF resources they have not used these resources under a conditional lending arrangement.

${ }^{4}$ Many studies have questioned the World Bank's role in fighting corruption (Marquette 2004; Polzer 2001) and designing and implementing reforms in Africa (Harrison 2005).
} 
France and the United Kingdom, have intervened to prevent the enforcement of conditionality. These kinds of weaknesses in program delivery may have deeper roots in the way in which both organizations are designed and influenced by powerful member states. ${ }^{5}$ A substantial literature has argued that both organizations could do more to be transparent, accountable, and democratic (Seabrooke 2007; Woods 2006; Thirkell-White 2005). ${ }^{6}$ It has been noted in some of this literature that African states, in particular, have very little input into decision-making: only two of the IMF's 24 Executive Directors are from African states. Both directors represent the interests of 42 sovereign states yet hold only 4.84 per cent of all votes - little in comparison to Germany, which by itself holds 5.81 per cent. $^{7}$

Despite the many criticisms of the IMF and World Bank in the academic literature, citizens in sub-Saharan Africa think that both organizations are doing their job well enough. Figures 1 and 2 show that a considerable majority of individuals rate the effectiveness of the IMF and the World Bank above 5 on an 11 point scale. In Malawi, approximately 40 per cent of those polled awarded a perfect score to both organizations, followed closely by Mozambique, and Lesotho. Surprisingly, respondents from Mali - the country with the longest continuous spell under an IMF program - awarded some of the highest ratings. Citizens in Botswana and Namibia, where there has been relatively little IMF and World Bank activity, awarded average ratings. By contrast, South Africans tend to be the more critical of both organizations, with a considerable number of citizens (but not a majority) awarding fewer than 5 out of 11 points. In the next section, we discuss the literature which attempts to explain variation in attitudes toward international economic organizations.

\section{Public opinion and international economic organizations}

Scholars of international relations have theorised the functions and benefits of international organizations, arguing that they have the potential to constrain great powers, provide information, reduce transaction costs, facilitate reciprocity among states, and facilitate reform in domestic politics (Keohane 1984; Milner 2005; Dai

\footnotetext{
${ }^{5}$ For recent work that has considered the question of control see Breen (2013), Stone (2011) and Copelovitch (2010).

${ }^{6}$ There is also a large literature on how voting rights should be re-allocated to strengthen legitimacy in the eyes of member states and the wider public (Martin and Woods 2005; Woods and Lombardi 2006; Rapkin and Strand 2006; Bradlow 2006; Meltzer 2007; Eichengreen 2007; Truman 2009).

${ }^{7}$ www.imf.org Access date: 13 October 2013.
} 
2007). While all of these functions can help developing countries, this literature has also identified a number of recurring problems with international organizations: sometimes they are simply not effective; sometimes they do not do their job well because of institutional design (Hawkins et al. 2006) and the accumulation of internal dysfunctions (Barnett and Finnemore 2004); and sometimes they are prone to capture by powerful countries and private interests (Stone 2011; Gould 2006). However, studies of international organizations do not often incorporate a view from the citizens. To our knowledge there are only two previous studies on the determinants of attitudes toward international economic organizations. These studies have explored variation in beliefs about a) the influence of international economic organizations and b) whether respondents trust them to manage globalization.

Utilizing data from the Pew Global Attitudes Survey conducted in 2002, Edwards (2009) analyzed responses to the question "Is the influence of international organizations like the IMF, World Bank and World Trade Organization very good, somewhat good, somewhat bad or very bad in (survey country)?" Edwards finds that more educated respondents are less inclined to support IEOs, women are more likely to support IEOs, and left-wing respondents are more likely to hold negative views of IEOs. Hessami (2011), using data from the Eurobarometer survey, analyzed responses to the question: "Globalization is a general opening up of all economies, which leads to the creation of a truly world-wide market. From the following list, who do you trust most to get the effects of globalization under control?" Hessami (2011) finds that a range of individual characteristics explain variation in trust more than evaluations of the economy. Like previous studies, we consider all of the key variables from the wider literature on attitudes toward economic reform. This literature emphasizes sociotropic variables, prospective views on the future path of the economy, education, and gender (Edwards 2009:188-191). Unlike previous studies, however, our dependent variable is coded from a question about the effectiveness of IEOs, rather than perceptions about trust and influence and we consider a number of additional key variables. We also argue that it is necessary to incorporate two key variables - trust and corruption - from the wider literature on attitudes toward international organizations. 
With few studies on the attitudes toward international economic organizations, the wider literature on attitudes to foreign policy and attitudes to other international organizations is relevant. Trust is a very important concept in this literature. In domestic politics, one of the main reasons why citizens trust government is because of its capacity to 'to make credible commitments, to design and implement policies nonarbitrarily, and to demonstrate competence.' (Levi and Stoker 2000:484). Trust is necessary because it is costly for citizens to know if government will act in their interests. The need for trust is even greater when one considers international organizations, whose inner workings and operations are opaque to most citizens. It is even more difficult for citizens in developing countries to obtain information about the IMF and the World Bank. Survey evidence demonstrates that citizens believe they have least influence at the international level (Vaubel 2006:125). Focusing on the United States, Brewer and Steenbergen (2002) find that citizens use interpersonal trust as a shortcut to help them understand foreign policy issues such as isolationism and international cooperation. Moreover, Brewer et al. (2004) find evidence that citizens who are cynical about politics are also cynical about international relations.

Even more relevant to our study is Torgler (2008), who finds that generalised trust, trust in domestic institutions, and the level of corruption, affects individuals' confidence in the United Nations (UN). Torgler's study on the extent to which individuals have 'confidence' in the UN is closely related to the question we are interested in - whether individuals think international economic organizations are effective. Like Torgler, we expect that trust and corruption should help to explain variation in attitudes toward international economic organizations. Citizens without enough information on the IMF and the World Bank will find it difficult to evaluate their effectiveness. In the absence of specific information on their activities, they may turn to their own positive or negative experience of domestic public institutions to rate IMF and World Bank effectiveness. If their own public institutions are of poor quality or demand bribes, this should influence their rating of the IMF and the World Bank downward. By contrast, if they participate in society more actively, this will build general trust and increase ratings. 
In summary, given the importance of trust and corruption as analytical tools for explaining support for international organizations, we expect that higher levels of trust will lead to higher ratings of the IMF and the World Bank. When trust in politics has been undermined, however, we expect to find lower ratings. Moreover, when individuals build trust through participation in society, the more they will trust international organizations. Based on these arguments, we propose to test the following hypotheses:

Hypothesis 1 A higher level of political trust is associated with more positive evaluations of the IMF and World Bank

Hypothesis 2 A higher level of (experienced) corruption is associated with less positive evaluations of the IMF and the World Bank

Hypothesis 3 Participation in civil society is associated with more positive evaluations of the IMF and the World Bank

\section{Data and Method}

The data for this paper come from round two of the Afrobarometer. The Afrobarometer is a representative cross sectional survey of public perceptions, social and economic conditions and political attitudes in sub-Saharan Africa. Round two was conducted in 2002 and 2003 in sixteen countries - Botswana, Cape Verde, Ghana, Kenya, Lesotho, Malawi, Mali, Mozambique, Namibia, Nigeria, Senegal, South Africa, Tanzania, Uganda, Zambia and Zimbabwe. ${ }^{8}$ All of these have the necessary data for our purposes bar Zimbabwe.

Our dependent variables come from the following question:

'Giving marks out of ten, where 0 is very badly and 10 is very well, how well do you think the following institutions do their jobs? Or haven't you heard enough about the institution to have an opinion? International Monetary Fund The World Bank'

\section{[FIGURES 1 and 2]}

\footnotetext{
${ }^{8}$ The data and full methodology can be obtained from www.afrobarometer.org.
} 
Figures 1 and 2 illustrate the distribution of our dependent variables by country and overall. The figures show substantial variation in the distribution of these variables both within and across countries. We can see from Table A1 that the mean value of each variable is about the same -6.3 for the IMF and 6.6 for the World Bank and both are highly correlated $(\approx 0.76)$.

To measure political trust we use information from several questions in the Afrobarometer that take the form 'How much do you trust each of the following, or haven't you heard enough about them to say?' We use the questions relating to the parliament, the army, the ruling party, the opposition, the courts, the police and the local government. Each of these can be answered 'not at all', 'a little bit', 'a lot' and ' $a$ very great deal' to which we assign the values 0-3 respectively. By summing over our seven categories we obtain an index of political trust that ranges from 0-21. ${ }^{9}$ Figure 3 shows that there is once again substantial within and cross country variation.

The Afrobarometer is particularly suited for testing Hypothesis 2 as it contains information on individuals' experience of corruption as opposed to perceptions. Specifically, it has information on how often the respondent has had to pay a bribe in several situations. The survey question is: 'In the past year, how often (if ever) have you had to pay a bribe, give a gift, or do a favour to government officials in order to $X$ ?' We use the questions on obtaining documents and permits, school placements, household services, avoiding problems with the police, and 'other.' The range of responses is 'never', 'once or twice', 'a few times' and 'often' to which we attach values 0-3 respectively. ${ }^{10}$ As in the case of political trust, we sum these to create an experience of corruption index which, in this case, takes values from 0-15. Figure 4 illustrates that in all countries more than half of all respondents have no experience of corruption (at least in the areas covered by the survey, which are fairly exhaustive). Even so, many people have some experience of this type of corruption, which varies greatly by country (4\% in Botswana, $21 \%$ in Ghana and $42 \%$ in Nigeria for example).

\section{[FIGURES 3 and 4$]$}

\footnotetext{
${ }^{9}$ We exclude trust in the presidency as the personality and leadership qualities of the individual may trump trust in the institution of the presidency.

${ }^{10}$ The survey in Mozambique allowed the additional response of 'always.' Very few people opted for this so we added those that did into the "often" group.
} 
To test Hypothesis 3, we make use of information regarding membership of a community development organization (CDA). The information comes from the question: '...could you tell me whether you are an official leader, an active member, an inactive member, or not a member (of a) community development or self-help association?' Specifically, we create a dummy variable which takes a value of one if the respondent reports that he is an "official leader" or "active member" of a CDA and zero otherwise. While CDAs (or self-help associations) can have many purposes, we are interested in capturing some level of participation in civil society. Figure 5 shows that there is variation in membership across the Afrobarometer countries. By our measurement, 19 per cent of our sample is active in civil society.

\section{[FIGURE 5]}

In line with previous studies on attitudes to international organizations, we control for a range of important factors identified in the literature on attitudes toward economic reform. First, we consider socio-demographic and economic variables including age, gender, urban or rural status, employment, health, level of education, a lived poverty index, and (perception of) relative living conditions. Second, we consider individuals' evaluations of the macro-economy. Taking inspiration from the literature on economic voting, we consider individuals' evaluations of the recent past, present, and prospects for the future (Lewis-Beck and Stegmaier 2000). The idea is that individuals may reward IEOs in economic good times and blame them in bad times. Moreover, individuals may act according to sociotropic models and reward IEOs for general economic performance, whereas individuals acting in accordance with 'pocketbook' explanations will reward IEOs for changes in their personal living conditions. Third, we control for a range of attitudes and ideological positions pertaining to employment, social identity, and the government's role in the economy, including attitudes to protectionism, inequality, the rating of government effectiveness with regards to price stability, group versus national identity, economic reforms versus hardships, and quantity versus quality of jobs.

Table A1 presents the mean and standard deviation of each of the variables used in this paper and provides a description of how the variables are coded. Our basic regression of interest is: 


$$
\operatorname{RATING}_{i}=\alpha+\beta_{1} P T_{i}+\beta_{2} C O R_{i}+\beta_{3} C D A_{i}+\beta_{\mathrm{x}} \mathrm{X}_{\mathrm{i}}+\varepsilon_{i}
$$

where $\operatorname{RATING}_{i}$ is the effectiveness rating given by individual $i$ to either the IMF or the World Bank; $P T_{i}$ is the political trust of individual $i ; C O R_{i}$ is the individual's experience of corruption; $C D A_{i}$ indicates whether the individual is a member of a community development association; $\mathrm{X}_{\mathrm{i}}$ represents the other variables; and $\varepsilon_{i}$ is an error term of the usual type.

\section{Explaining attitudes toward the IMF and the World Bank}

\section{Main Results}

Table 1 presents our key findings from OLS. As expected, the political trust index is highly statistically significant and positively associated with ratings of the IMF and the World Bank. Moreover, the size of the effect is meaningful. Taking the results from the models with all variables included (columns 4 and 8), a one standard deviation increase in the political trust index $(\approx 4.7)$ suggests an increase of roughly 0.31 of a unit on our 0-10 IMF rating scale and roughly 0.34 of a unit on the World Bank scale - a very similar magnitude. This is about 12 per cent of a standard deviation in the IMF variable (mean 6.3, SD 2.6) and roughly 13 per cent in the case of the World Bank variable (mean 6.6, SD 2.6). Taken together, this lends support to $\mathrm{H} 1$, suggesting that those who place more trust in domestic political institutions believe that the IMF and World Bank are doing a better job. Our findings also lend support to $\mathrm{H} 2$ and $\mathrm{H} 3$. The experience of bribery index is statistically significant in all specifications. Individuals who have experienced more corruption tend to think that the IMF and the World Bank are less effective. A one standard deviation increase in the bribery index $(\approx 1.8)$ is associated with a 0.12 unit decrease in the effectiveness rating awarded to both organizations. ${ }^{11}$ We find that membership of a community development association (CDA) is a significant correlate of World Bank ratings. The size of the effect is similar to political trust effect above $(\approx 0.25$ of a unit on our $0-10$ scale). In our results for the IMF, CDA membership is significant at 95 per cent level in all but one of our specifications. One potential explanation for why the World Bank

\footnotetext{
${ }^{11}$ Our indices for political trust and experience of bribery impose the restriction that each of their elements and intensities matters equally. To test whether our results are robust to this restriction, we created alternative measures using principal component analysis. The details are available on request and the results are near identical.
} 
results are stronger is that their work is more relevant to community development associations and regional and subnational development projects.

Surprisingly, we find little evidence that evaluations of the macro-economy are associated with how people view the effectiveness of these organizations. Similarly, a range of attitudes to government and society do not determine ratings of either organization. Ideological positions that are often presented as decisive, such as attitudes towards protectionism, income inequality and the role of government in society, do not appear to influence ratings. Even more surprisingly, attitudes to economic reform, a central function of both organizations, are not associated with ratings. However, age and higher education are consistently associated with worse evaluations of the World Bank but not the IMF. Again, as we have already alluded to, the Bank is more focused on development issues; its programs extend into many sectors, including agriculture, education, public administration, and governance. Older and more educated individuals may have more knowledge and experience of failures in development and may associate this with the World Bank. Nevertheless, some of the most serious challenges facing many people in sub-Saharan Africa, including, poor health, high poverty and unemployment, do not shape attitudes toward the IMF or World Bank. ${ }^{12}$ This is surprising, especially in the case of the World Bank, who explicitly target health and lived poverty. Taken together, our findings suggest that political trust and corruption are closely associated with attitudes, trumping most other observable characteristics. However, it is important to note that unobservable individual-specific characteristics are likely to be very important. For example, we have no way of directly observing if an individual has benefited from a World Bank project or if an individual had a negative experience because of IMF or World Bank policies.

We performed two robustness tests. In the first test, we present our estimates using an ordered probit model. This is necessary because it is easy to question whether a ' 5 ' on our 0-10 scale represents the same sentiment toward the IMF and the World Bank in Mali as in Mozambique. The best way to address this problem in the absence of panel

\footnotetext{
${ }^{12}$ We repeated the test using income deciles instead of our lived poverty index. This halves our sample and as the results are qualitatively similar we favour our poverty index. Results using this alternative are on request.
} 
data or a method like anchoring vignettes is to create broader categories. ${ }^{13}$ We create 6 categories: a zero category along with five others each taking two points on the original 0-10 scale. Table 2 presents the marginal effects for our main variables of interest. The two specifications correspond to those of columns 4 and 8 in Table 1 and the results are in agreement with our findings above. In the second robustness test, we dropped attitudinal variables from columns 1 and 5 in Table 1. We did this because Fordham and Kleinberg (2012) have argued that attitudes towards economic policy are unlikely to be causally related. Excluding these variables (including political trust) does not alter our findings on the effect of corruption and CDA membership.

\section{Who has an opinion? Why do people favour one institution?}

The data allow us to extend the analysis to examine why individuals have favoured one institution over the other, and why some individuals have an opinion in the first place. For the first of these questions, we have created two sets of dependent variables. The first takes a value of one if the rating of institution $\mathrm{X}$ is greater than that of $\mathrm{Y}$ and 0 if the rating of $\mathrm{X}$ is equal to or less than the rating of $\mathrm{Y}$ (IMFMORE and BANKMORE). The second takes a value of one if the rating of institution $\mathrm{X}$ is greater than that of $\mathrm{Y}$ and 0 if the rating of $\mathrm{X}$ is less than the rating of $\mathrm{Y}$ (IMFMORE2 and BANKMORE2). These are obviously two very closely related ways of looking at the question.

Using the first set of dependent variables, we can see from the first two columns of Table 3 that women are more likely to rate the IMF as more effective than the World Bank. Older people are less likely to rate the World Bank as the more effective of the two. Poor health is related to a higher probability of rating the World Bank more than the IMF and vice versa. This may seem inconsistent but one must remember that those who rate the institutions equally are in the reference category. Thus, this result may be interpreted as saying that having worse health makes you more likely to rate one of the institutions as more effective. Finally, feeling that the country's current

\footnotetext{
${ }^{13}$ A different way to address this issue this is to run a simple binary probit with some threshold for a good evaluation. When we do this with a threshold of 5 , both political trust and experience of corruption are highly significant for the IMF though for the World Bank political trust is significant at $1 \%$ but corruption only at $10 \%$. CDA membership is not significant in either case. Results available on request.
} 
economic conditions are bad is negatively associated with rating the IMF as the more effective.

The second approach is necessarily symmetric. In columns 3 and 4 of Table 3, only gender matters, with women rating the IMF as the more effective agency. Taken together, these findings suggest that there is some role for personal characteristics and evaluations of the economy to matter for ratings of effectiveness. While they do not seem to explain variation in individuals' ratings they do explain why individuals discriminate among institutions. There are a number of possible reasons why. One may be that one institution is more visible than the other in a specific policy area. Another is that one institution might target different groups or at least affect areas that different groups care about. Moreover, some groups may be more sensitive to the policies and programmes of one institution. A substantial literature has argued that IMF and World Bank programmes have harmed women in Africa (Gladwin 1991; Sparr 1994; Emeagwali 1995). Therefore, a plausible interpretation of our finding is that women might perceive the World Bank as more harmful due to its visibility, and consequently tend to award the IMF a higher rating.

The second of our extensions, the question of why people have an opinion in the first place, is addressed in columns 5 and 6 (IMFOP and BANKOP). The reason we look at the determinants of opinion formation is that 52 per cent and 46 per cent of respondents answered 'Don't know/haven't heard enough' when asked to rate the IMF and World Bank respectively. Looking at the two last specifications in Table 3, we can see that there is a role for personal characteristics in the formation of opinions. Being a woman, a perception of worse relative living conditions, and negative appraisals of the current state of the economy are negatively associated with having an opinion of each institution. Living in an urban area, education (at each stage), experience of corruption, membership of CDA, and having a government salary in the household are positively associated with having an opinion of each institution. The only factor that is significant in one case and not the other is satisfaction with the government's reduced economic role, which is positively associated with having an opinion about the IMF. These findings stand in contrast to our earlier findings on ratings, which tend to focus exclusively on political trust, corruption and involvement 
in a CDA. Personal characteristics do seem to play a role in what could be seen a first stage of a ratings formation process. ${ }^{14}$

\section{Conclusions}

The question of whether international organizations are working is a vital question for a substantial literature on globalization, development and international organizations (Buchanan and Keohane 2006; Barnett and Duvall 2005; McGrew and Held 2002). What this literature - and the debate about whether IEOs are working - is often missing is a view from the citizens. In this article, we have illustrated a strong association between ratings of the IMF and the World Bank, political trust, corruption and participation in civil society. By contrast, a range of personal characteristics, socio-demographic factors, and ideological dispositions did not affect individuals' ratings but did contribute somewhat to opinion formation and differential assessments of both organizations. Our findings suggest that if the IMF and the World Bank wish to build legitimacy they need to ask whether, and under what conditions, their programs might undermine trust in government. More research is needed to understand the extent to which programs might undermine trust and how programs can be designed to build trust in public institutions. ${ }^{15}$ Our findings suggest that supporting and engaging with civil society and supporting measures to curb corruption may help to build legitimacy.

As well as contributing to the debate about whether international organizations are working, our findings also contribute modestly to an important debate about the responsibilities and obligations of international institutions to help developing countries. Within this debate, Pogge (2002) has argued that not only have international institutions failed to live up to their obligations but that they are harming poor countries and have an obligation to stop. Rawls (1999), on the other hand, has argued that justice is relevant only domestically and that no such obligation applies.

\footnotetext{
${ }^{14}$ In an additional robustness test we have modeled this as a two stage process where the first stage is a 'decision' to have an opinion about the IMF or the World Bank and the second stage is the decision to award a rating from $0-10$. We did this by generating a predicted probability from the first stage model and including it as an additional explanatory variable in the second stage. The results were broadly similar except that bribery is only significant at $10 \%$ for the World Bank. Full results available on request.

${ }^{15}$ Existing studies suggest that programs can be highly disruptive. For example, Hartzell et al. (2010) have found an association between the adoption of IMF programs and the onset of civil war.
} 
Public opinion research of citizens in developing countries can help to inform this debate by illustrating how citizens view international institutions and whether they perceive harm, inefficiency, irrelevance or threat. Our basic findings suggest that citizens in sub-Saharan Africa relate to international economic organizations as if they were another feature of domestic politics, and believe that for the most part they are working well enough.

\section{References}

Abouharb, M. Rodwan, and David L. Cingranelli. 2006. "The Human Rights Effects of World Bank Structural Adjustment, 1981-2000." International Studies Quarterly 50 (2):233-62.

Barnett, Michael N., and Raymond Duvall, eds. 2005. Power in global governance. Cambridge: Cambridge University Press.

Barnett, Michael N., and Martha Finnemore. 2004. Rules For the World: International Organizations in Global Politics. Ithaca, NY: Cornell University Press.

Bird, Graham, Mumtaz Hussain, and Joseph P. Joyce. 2004. "Many Happy Returns? Recidivism and the IMF." Journal of International Money and Finance 23 (2):231-51.

Bradlow, Daniel D. 2006. "The Governance of the IMF: The Need for Comprehensive Reform." Paper prepared for the Meeting of the G24 Technical Committee, Singapore, September 2006.

Breen, Michael. 2013. The Politics of IMF Lending. Basingstoke: Palgrave Macmillan.

Brewer, Paul R., Kimberly Gross, Sean Aday, and Lars Willnat. 2004. "International Trust and Public Opinion About World Affairs." American Journal of Political Science 48 (1):93-109.

Brewer, Paul R., and Marco R. Steenbergen. 2002. "All Against All: How Beliefs about Human Nature Shape Foreign Policy Opinions." Political Psychology 23 (1):39-58.

Buchanan, Allen, and Robert O. Keohane. 2006. "The legitimacy of global governance institutions." Ethics \& International Affairs 20 (4):405-37.

Collier, Paul, and Jan Willem Gunning. 1999. "Why Has Africa Grown Slowly?" Journal of Economic Perspectives 13 (3).

Conway, Patrick. 2007. "The Revolving Door: Duration and Recidivism in IMF Programs." The Review of Economics and Statistics 89 (2):205-20.

Copelovitch, Mark S. 2010. The International Monetary Fund in the Global Economy: Banks, Bonds, and Bailouts. Cambridge: Cambridge University Press.

Crisp, Brian F., and Michael J. Kelly. 1999. "The Socioeconomic Impacts of Structural Adjustment." International Studies Quarterly 43 (3):533-52.

Dai, Xinyuan. 2007. International Institutions and National Policies. Cambridge: Cambridge University Press. 
Easterly, William. 2005. "What did Structural Adjustment Adjust? The Association of Policies and Growth with Repeated IMF and World Bank Adjustment Loans." Journal of Development Economics 76 (1):1-22.

Edwards, Martin S. 2009. "Public support for the international economic organizations: Evidence from developing countries." Review of International Organizations 4:185-209.

Eichengreen, Barry. 2007. "A Blueprint for IMF Reform: More than just a Lender." International Finance 10 (2):153-75.

Emeagwali, G. 1995. Women pay the price: Structural adjustment in Africa and the Caribbean. Trenton: Africa World.

Fordham, Benjamin O., and Katja B. Kleinberg. 2012. "How Can Economic Interests Influence Support for Free Trade?" International Organization 66 (2):311-28.

Gladwin, Christina H., ed. 1991. Structural adjustment and African women farmers. Gainesville: University of Florida Press.

Gould, Erica R. 2006. Money Talks: The International Monetary Fund, Conditionality and Supplementary Financiers. Chicago: Stanford University Press.

Harrison, Graham. 2005. "The World Bank, governance and theories of political action in Africa." The British Journal of Politics \& International Relations 7 (2):240-60.

Hartzell, Caroline A., Matthew Hoddie, and Molly Bauer. 2010. "Economic Liberalization via IMF Structural Adjustment: Sowing the Seeds of Civil War?" International Organization 64 (2):339-56.

Hawkins, Darren G., David A. Lake, Daniel L. Nielson, and Michael J. Tierney, eds. 2006. Delegation and Agency in International Organizations. Cambridge: Cambridge University Press.

Hessami, Zohal. 2011. "What Determines Trust in International Organizations? An Empirical Analysis for the IMF, the World Bank, and the WTO." University of Konstanz Department of Economics Working Paper Series 2011-44.

Keohane, Robert O. 1984. After Hegemony: Cooperation and Discord in the World Political Economy. Princeton, NJ: Princeton University Press.

Levi, Margaret, and Laura Stoker. 2000. "Political Trust and Trustworthiness." Annual Review of Political Science 3 (1):475-507.

Lewis-Beck, Michael S., and Mary Stegmaier. 2000. "Economic determinants of electoral outcomes." Annual Review of Political Science 3:183-219.

Marquette, Heather. 2004. "The Creeping Politicisation of the World Bank: The Case of Corruption." Political Studies, 2004, 52, 3, Oct, 413-430.

Marshall, Katherine. 2008. The World Bank: From Reconstruction to Development to Equity. London: Routledge.

Martin, Lisa, and Ngaire Woods. 2005. "Multiple-State Constituencies in the IMF: An Agency Approach." Reforming the IMF? Governance and the Executive Board, Sixth Jacques Polak Annual Research Conference, November 3-4. 2005.

McGrew, Anthony, and David Held. 2002. Governing globalization: power, authority and global governance: Polity Press.

Meltzer, Allan H. 2007. "A Blueprint for IMF Reform: What is Worth Retaining?" International Finance 10 (2):177-82.

Milner, Helen V. 2005. "Globalization, Development, and International Institutions: Normative and Positive Perspectives." Perspectives on Politics 3 (4):833-54. 
Noorbakhsh, Farhad, and Alberto Paloni. 2001. "Structural Adjustment and Growth in Sub-Saharan Africa: The Importance of Complying with Conditionality." Economic Development and Cultural Change 49 (3):479-509.

Pogge, Thomas W. 2002. World poverty and human rights. Cambridge: Polity.

Polzer, Tara. 2001. "Corruption: deconstructing the World Bank discourse." Development Studies Institute (DESTIN) Working Paper:1.

Rapkin, David P., and Jonathan R. Strand. 2006. "Reforming the IMF's Weighted Voting System." The World Economy 29 (3):305-24.

Rawls, John. 1999. The law of peoples; with, the idea ofpublic reason revisited. Cambridge: Harvard University Press.

Seabrooke, Leonard. 2007. "Legitimacy Gaps in the World Economy: Explaining the Sources of the IMF's Legitimacy Crisis." International Politics 44:250-68.

Sparr, P. 1994. Mortgaging women's lives: Feminist critiques of structural adjustment. London: Zed.

Stone, Randall. 2004. "The Political Economy of IMF Lending in Africa." American Political Science Review 98 (4):577-91.

Stone, Randall W. 2011. Controlling Institutions: International Organizations and the Global Economy. Cambridge: Cambridge University Press.

Thirkell-White, Ben. 2005. The IMF and the Politics of Financial Globalization: From the Asian Crisis to a New International Financial Architecture? Basingstoke: Palgrave Macmillan.

Torgler, Benno. 2008. "Trust in international organizations: An empirical investigation focusing on the United Nations." The Review of International Organizations 3 (1):65-93.

Truman, Edwin M. 2009. "The IMF and the Global Crisis: Role and Reform." In Remarks delivered to the Tulsa Committee on Foreign Relations and Dallas Committee on Foreign Relations Peterson Institute for International Economics.

Vaubel, Roland. 2006. "Principal-Agent Problems in International Organisations." The Review of International Organizations 1 (2):125-38.

Vreeland, James R. 2003. "Why do Governments and the IMF Enter into Agreements? Statistically Selected Cases." International Political Science Review 24 (3):321-43.

Vreeland, James Raymond. 2007. The International Monetary Fund: Politics of Conditional Lending. New York: Routledge.

Winters, Matthew S. 2010. "Choosing to Target: What Types of Countries Get Different Types of World Bank Projects." World Politics 62 (3):422-58.

Woods, Ngaire. 2006. The Globalizers, The IMF, The World Bank and their Borrowers. Ithaca NY: Cornell University Press.

Woods, Ngaire, and Domenico Lombardi. 2006. "Uneven Patterns of Governance: How Developing Countries Are Represented in the IMF." Review of International Political Economy 13 (3):480-515. 


\section{FIGURE 1}

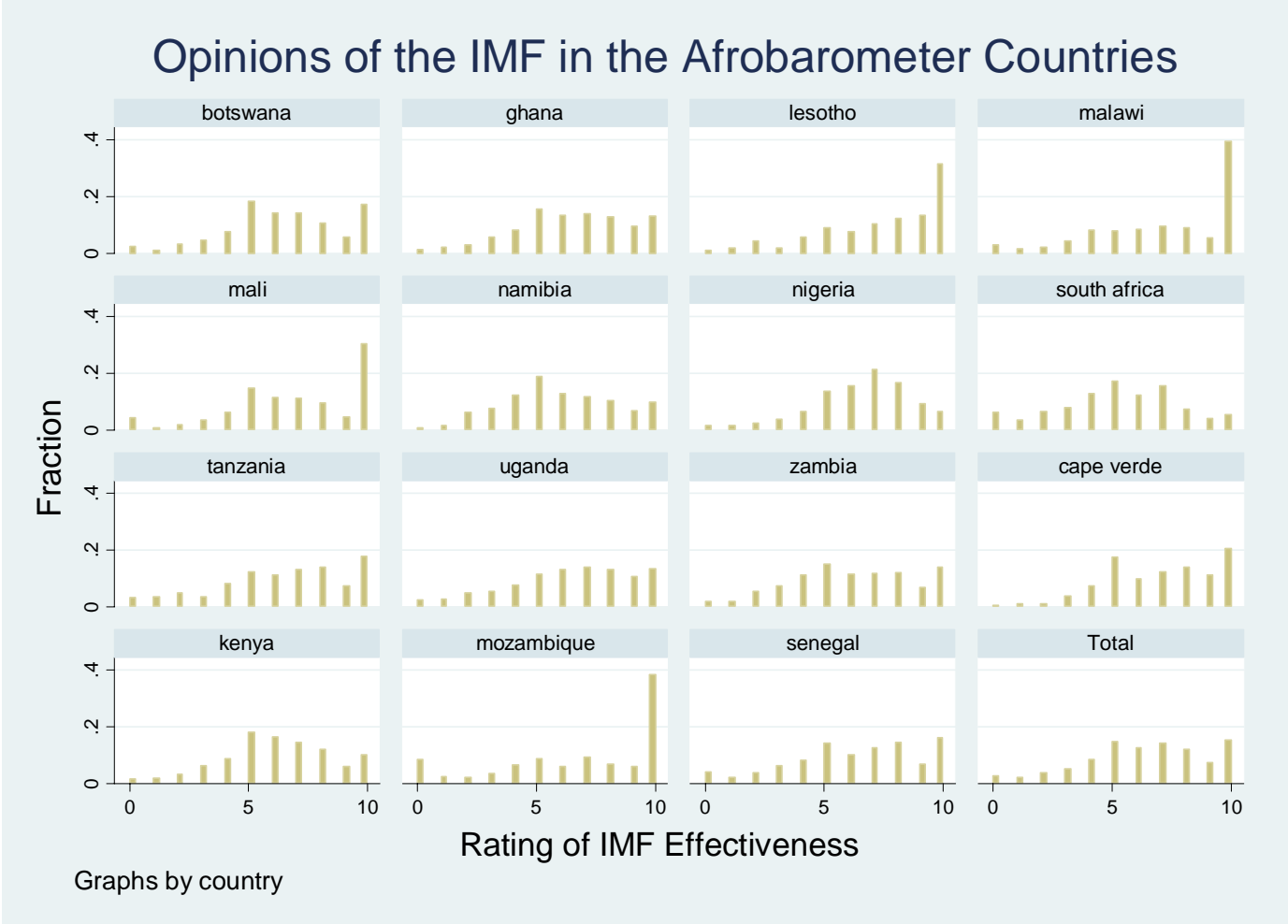

\section{FIGURE 2}

Opinions of the World Bank in the Afrobarometer Countries
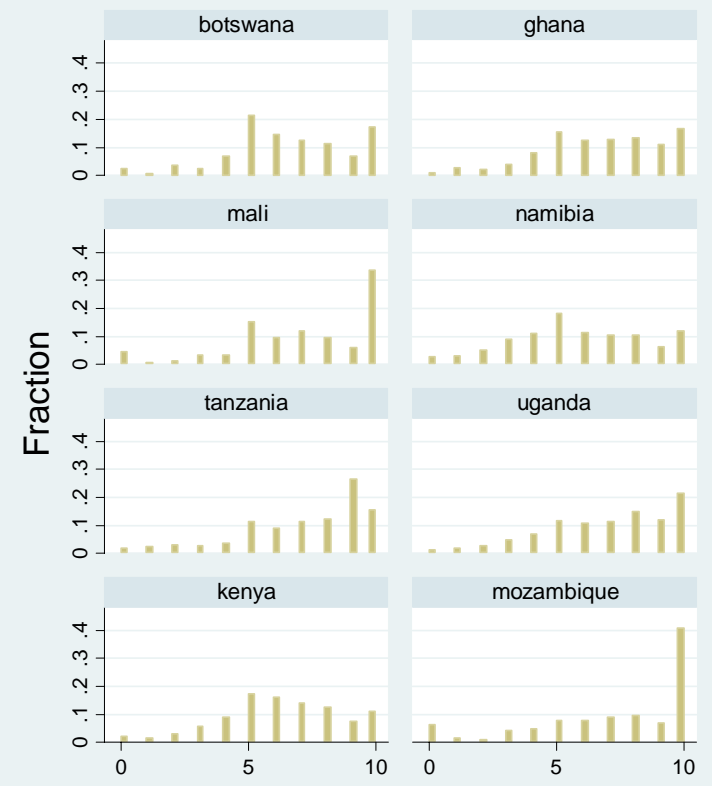

lesotho

malawi

namibia
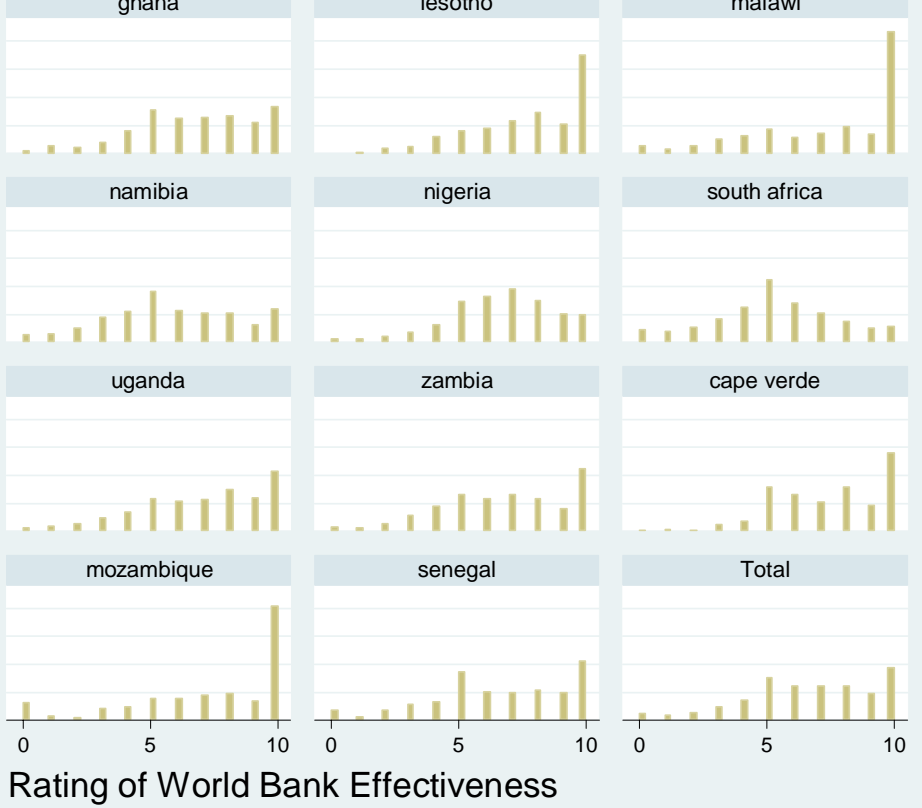

Graphs by country 
FIGURE 3

Political Trust in the Afrobarometer Countries

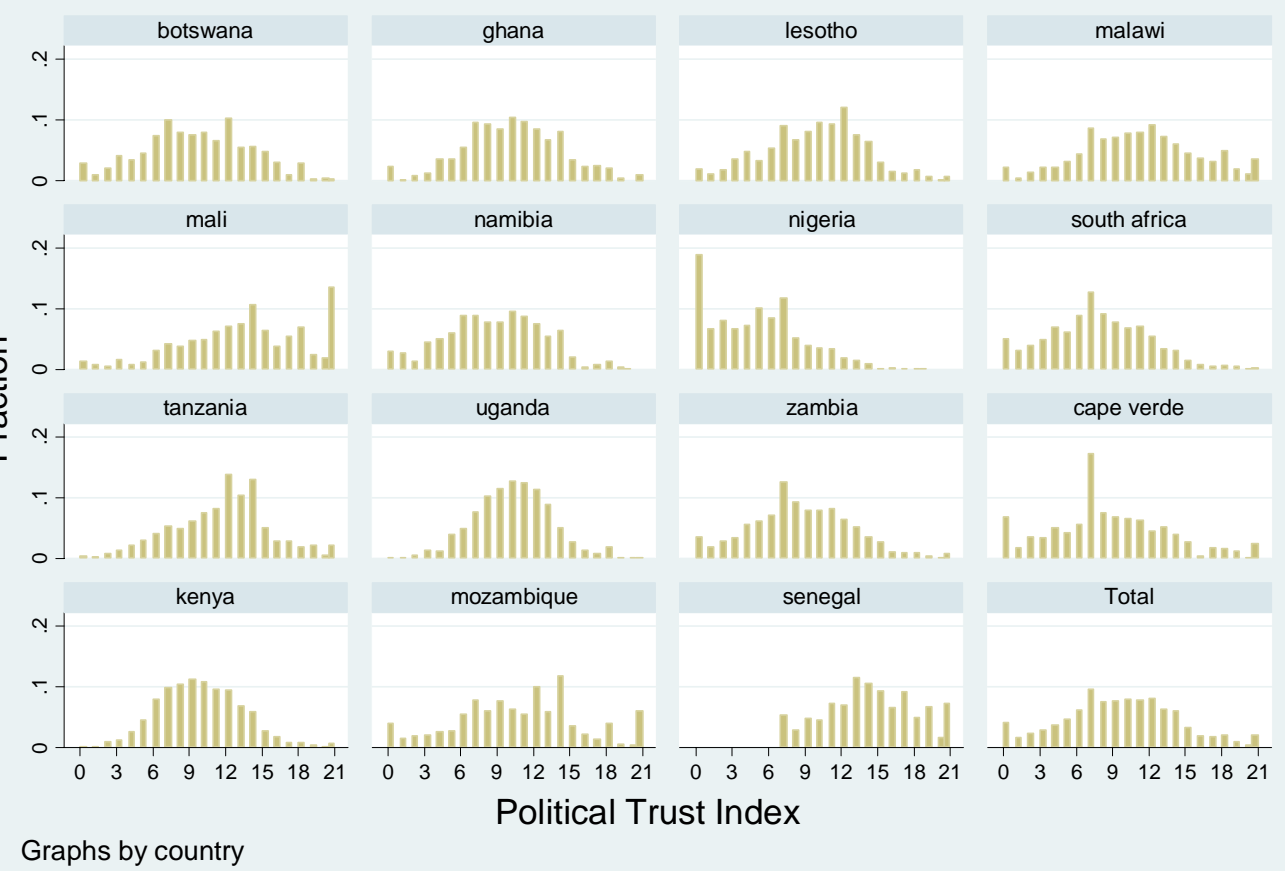

\section{FIGURE 4}

Experience of Corruption in the Afrobarometer Countries

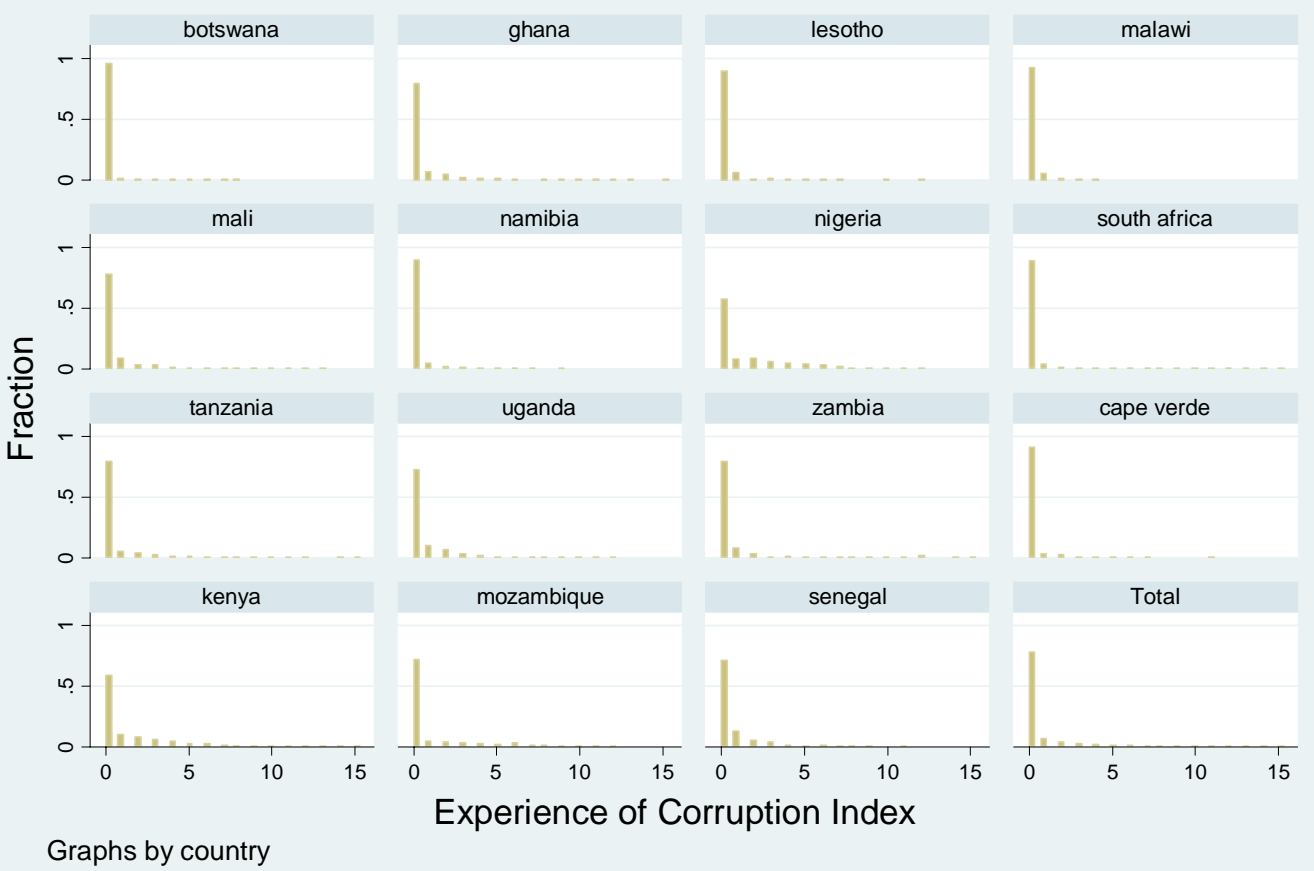




\section{FIGURE 5}

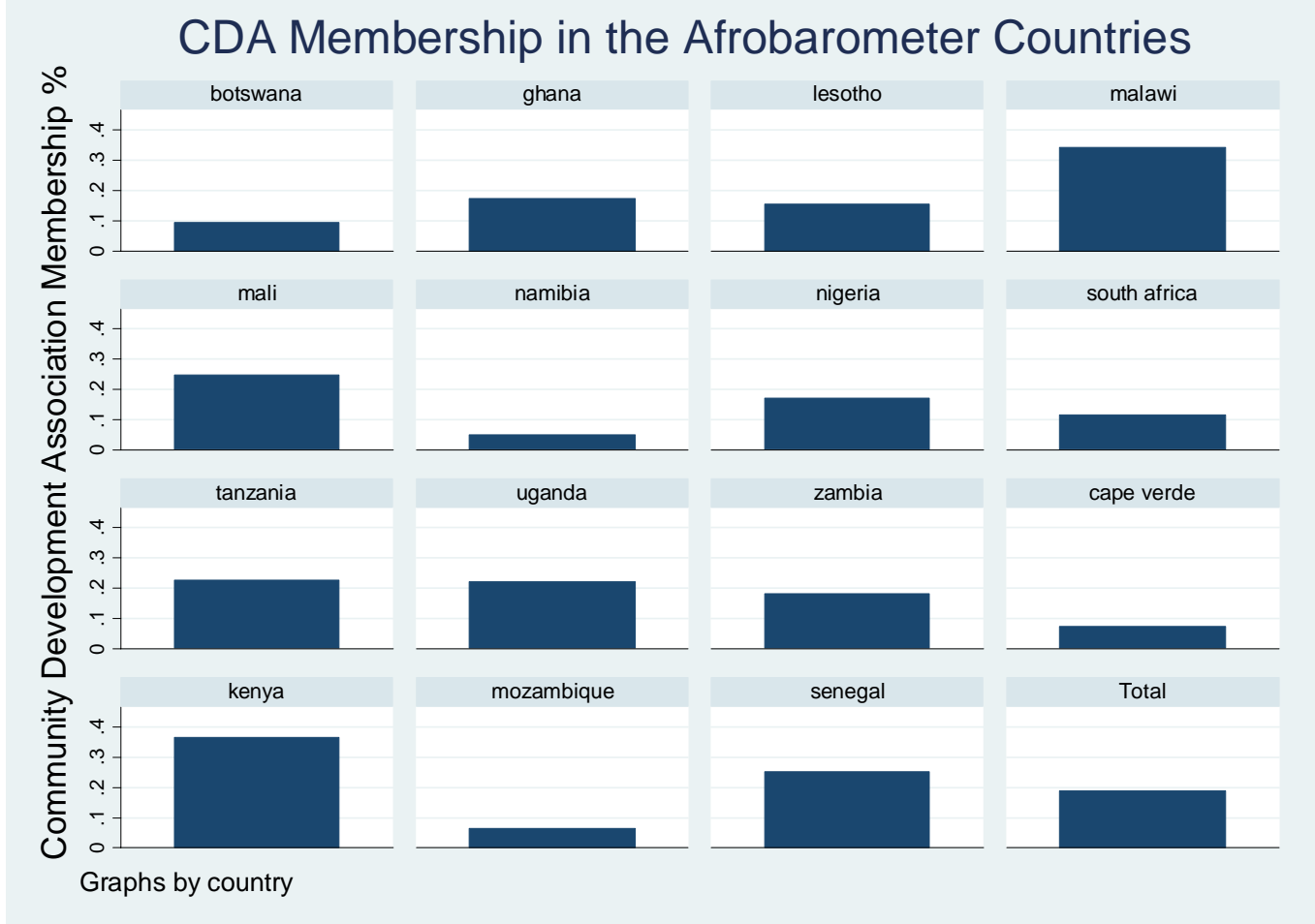




\section{TABLE 1: Explaining variation in ratings of the IMF and World Bank}

Political Trust (0-21 Scale)

Bribe Experience (0-15 Scale)

Member of Community Development Association

Age

Female Dummy

Urban Dummy

Unemployed Dummy

Health (0-6 scale)

Primary or Some Secondary Education (relative to Less than full primary)

Secondary Education

(relative to Less than full primary)

Post Secondary

(relative to Less than full primary)

University Complete or Postgrad

(relative to Less than full primary)

Poverty (0-24 Scale)

Perception of Worse Relative Living Conditions

Government Salary in Household

Protectionist Dummy

\section{(1)}

$0.0806^{* * * *}$

(0.0112)

$-0.0502 * *$

(0.0232)

$0.210 * *$

(0.102)

$-0.00494 *$

(0.00262)

0.0714

(0.0603)

$-0.0963$

(0.0892)

0.0879

(0.100)

0.00865

(0.0359)

$-0.0366$

(0.0980)

$-0.0237$

(0.116)

$-0.205$

(0.147)

$-0.314^{*}$

(0.174)

$-0.00930$

(0.00843)

0.115

(0.0830)

0.0424

(0.0789)
(2)

\section{IMF}

\section{$0.0768 * * *$}

$-0.0533 * *$

(0.0240)

$0.233 * *$

(0.106)

$-0.00597 * *$

(0.00285)

0.0779

(0.0620)

$-0.0762$

(0.0905)

0.0794

(0.0997)

$-0.0124$

(0.0370)

$-0.0280$

(0.105)

$-0.0155$

(0.123)

$-0.221$

(0.152)

$-0.336^{*}$

(0.180)

$-0.00899$

(0.00850)

$0.190 * *$

(0.0782)

0.0507

(0.0811)
(4)

$(0.0120)$

$0.0665 * * *$ (0.0127)

$-0.0630 * *$

$-0.0685^{* * *}$

(0.0262)

0.249 **

$0.212 *$

(0.120)

$-0.00492$

$(0.00328)$

0.0597

(0.0745)

$-0.126$

(0.0923)

0.0815

(0.118)

$-0.00568$

(0.0418)

0.000163

(0.123)

$-0.0377$

(0.149)

$-0.196$

(0.159)

$-0.276$

(0.202)

$-0.0140$

(0.0104)

$0.166^{*}$

(0.0958)

0.114

(0.0913)

$-0.0180$
(0.124)

$-0.00529$

(0.00346)

0.0758

(0.0768)

$-0.102$

(0.0929)

0.0465

$(0.120)$

$-0.0293$

$(0.0423)$

0.0380

(0.122)

$-0.0198$

(0.153)

$-0.182$

(0.156)

$-0.265$

(0.201)

$-0.0139$

(0.0108)

$0.210 * *$

(0.0919)

0.117

(0.0932)

$-0.0180$
(5)

$0.0790 * * *$

(0.00966)

$-0.0566 * * *$

(0.0197)

(0.0860)

$-0.00718 * *$

(0.00258)

0.0380

(0.0475)

$-0.0439$

(0.0836)

0.0476

$(0.0895)$

0.0175

(0.0318)

$-0.0581$

(0.0836)

$-0.103$

(0.0972)

$-0.351 * * *$

(0.130)

$-0.537 * *$

(0.178)

$-0.00580$

(0.00762)

0.0768

$(0.0755)$

0.0735

(0.0669)
(6)

WORLD BANK

$0.0761 * *$

$(0.0110)$

(8)

$-0.0618 * * * \quad-0.0580 * * * \quad-0.0656 * * *$

(0.0222)

$-0.0656^{* * * *}$

$0.251 * * * \quad 0.206 * * \quad 0.239 * *$

$(0.0902)-(0.101)$

$(0.105)$

$-0.00929 * * * \quad-0.00682 * * \quad-0.00912 * * *$

$(0.00273)$

$(0.00329)$

0.029

$-0.00386$

$-0.0126$

$(0.0499)$

$(0.0581)$

$(0.0607)$

$-0.0403 \quad 0.00314$

0.0107

$(0.0831)$

0.0103

(0.0899)

(0.0889)

$(0.0890)$

0.00975

(0.0330)

0.00907

$(0.0902)$

$-0.102$

(0.105)

$-0.355^{* *}$

$(0.136)$

$-0.510 * * *$

(0.182)

$-0.00603$

$(0.00797)$

$0.125^{*}$

(0.0737)

0.0631

(0.0707)

$(0.0362)$

$(0.104)$

$-0.00315$

$(0.0369)$

$-0.00318$

(0.110)

(0.109)

.098

$-0.122$

$(0.133)$

$-0.298^{* *}$

(0.150)

$-0.309 * *$

(0.149)

$-0.496 * *$

$-0.482 * *$

(0.203)

$-0.00660$

$-0.00704$

$0.0101)$

0.0735

0.132

(0.0884)

0.0850

0.108

(0.0817)

(0.0844)

0.0150 
Prefers Fewer Jobs with High Wages

to More Jobs with Low Wages

Rating of Governments Efforts at Price Stability

Inequality OK Dummy

Abandon economic reforms vs. accept hardships

Dummy

Satisfied with government's reduced economic role

Dummy

Group Vs National Identity Dummy

Views Country's present economic condition

as Bad Dummy

Country's economic condition 12 months ago was

Worse Dummy

Pessimistic about Country's economic condition

in 12 months

Constant

Observations

R-squared

Standard E

\begin{tabular}{|c|c|c|c|c|c|}
\hline$(0.100)$ & $(0.104)$ & & & $(0.0913)$ & $(0.0982)$ \\
\hline-0.0110 & -0.0482 & & & 0.0266 & 0.0369 \\
\hline$(0.125)$ & $(0.132)$ & & & $(0.117)$ & $(0.121)$ \\
\hline 0.162 & $0.192 *$ & & & 0.0704 & 0.0689 \\
\hline$(0.107)$ & $(0.108)$ & & & $(0.102)$ & $(0.0997)$ \\
\hline 0.0808 & 0.0785 & & & 0.0637 & 0.0684 \\
\hline$(0.0900)$ & $(0.0973)$ & & & $(0.0811)$ & $(0.0840)$ \\
\hline-0.0537 & -0.0756 & & & -0.0638 & -0.111 \\
\hline$(0.0934)$ & $(0.102)$ & & & $(0.0747)$ & $(0.0812)$ \\
\hline 0.0446 & 0.0234 & & & 0.0322 & -0.00555 \\
\hline$(0.107)$ & $(0.107)$ & & & $(0.102)$ & (0.109) \\
\hline-0.109 & $-0.167^{*}$ & & & -0.0459 & -0.0976 \\
\hline \multirow[t]{7}{*}{$(0.0967)$} & $(0.101)$ & & & $(0.0990)$ & $(0.107)$ \\
\hline & -0.0485 & & -0.0174 & & 0.0209 \\
\hline & $(0.0893)$ & & $(0.0810)$ & & $(0.0906)$ \\
\hline & -0.00666 & & -0.0354 & & -0.0805 \\
\hline & $(0.102)$ & & $(0.0787)$ & & $(0.0868)$ \\
\hline & -0.0938 & & $-0.128 *$ & & -0.0911 \\
\hline & $(0.0959)$ & & $(0.0747)$ & & $(0.0826)$ \\
\hline $6.308 * * *$ & $6.347 * * *$ & $6.099 * * *$ & $6.156 * * *$ & $6.232 * * *$ & $6.386 * * *$ \\
\hline$(0.362)$ & $(0.383)$ & $(0.226)$ & $(0.245)$ & $(0.313)$ & $(0.342)$ \\
\hline 6,200 & 5,695 & 9,143 & 8,236 & 6,847 & 6,222 \\
\hline 0.064 & 0.065 & 0.077 & 0.079 & 0.074 & 0.076 \\
\hline
\end{tabular}


TABLE 2: Explaining variation in ratings of the IMF and World Bank

\begin{tabular}{|c|c|c|c|c|c|c|}
\hline & (1) & (2) & (3) & (4) & $(5)$ & (6) \\
\hline CATEGORY: & 0 & $1-2$ & $3-4$ & $5-6$ & $7-8$ & $9-10$ \\
\hline & \multicolumn{6}{|c|}{ IMF } \\
\hline Political Trust (0-21 Scale) & $\begin{array}{c}-.0015167 * * * \\
(0.00033)\end{array}$ & $\begin{array}{c}-0.0026263^{* * * *} \\
(0.00049)\end{array}$ & $\begin{array}{c}-0.0043356^{* * * *} \\
(0.00078)\end{array}$ & $\begin{array}{c}-0.0029904 * * * \\
(0.00057)\end{array}$ & $\begin{array}{c}0.0027974 * * * \\
(0.00058)\end{array}$ & $\begin{array}{c}0.0086717 * * * * \\
(0.00154)\end{array}$ \\
\hline Bribe Experience (0-15 Scale) & $\begin{array}{c}0.0015536 * * * \\
(0.00057)\end{array}$ & $\begin{array}{c}0.0026903 * * * \\
(0.00097)\end{array}$ & $\begin{array}{c}0.0044412 * * * \\
(0.00164)\end{array}$ & $\begin{array}{c}0.0030632 * * * \\
(0.00109)\end{array}$ & $\begin{array}{c}-0.0028655^{* * * *} \\
(0.00108)\end{array}$ & $\begin{array}{c}-0.0088828 * * * \\
(0.00316)\end{array}$ \\
\hline Member of Community Development & $-0.0060966^{* *}$ & $-0.0108183^{* *}$ & $-0.0183238 * *$ & $-0.0134716^{* *}$ & $0.0110514 * * *$ & $0.037659 * *$ \\
\hline Association & $(0.00268)$ & $(0.00453)$ & $(0.00773)$ & $(0.00616)$ & $(0.00419)$ & $(0.01684)$ \\
\hline \multirow[t]{2}{*}{ Observations } & 5695 & 5695 & 5695 & 5695 & 5695 & 5695 \\
\hline & \multicolumn{6}{|c|}{ WORLD BANK } \\
\hline Political Trust (0-21 Scale) & $\begin{array}{c}-0.0013038^{* * *} \\
(0.00028)\end{array}$ & $\begin{array}{c}-0.0022455^{* * * *} \\
(0.0004)\end{array}$ & $\begin{array}{c}-0.0043385^{* * *} \\
(0.00067)\end{array}$ & $\begin{array}{c}-0.0042805^{* * *} \\
(0.00064)\end{array}$ & $\begin{array}{c}0.001758 * * * \\
(0.00038)\end{array}$ & $\begin{array}{c}0.0104103 * * * \\
(0.00155)\end{array}$ \\
\hline Bribe Experience (0-15 Scale) & $\begin{array}{c}0.0011869^{* * *} \\
(0.00041)\end{array}$ & $\begin{array}{c}0.0020443^{* * *} * \\
(0.00064)\end{array}$ & $\begin{array}{c}0.0039496 * * * \\
(0.00133)\end{array}$ & $\begin{array}{c}0.0038968^{* * *} \\
(0.0013)\end{array}$ & $\begin{array}{c}-0.0016004 * * * \\
(0.0006)\end{array}$ & $\begin{array}{c}-0.0094772 * * * \\
0.00306\end{array}$ \\
\hline Member of Community Development & $-0.0045418 * *$ & $-0.0079913^{* *}$ & $-0.0157771^{* *}$ & $-0.0163114^{* *}$ & $0.0057119 * *$ & $0.0389097 * *$ \\
\hline Association & $(0.00201)$ & $(0.00324)$ & $(0.00638)$ & $(0.00693)$ & $(0.00222)$ & $(0.01633)$ \\
\hline Observations & 6222 & 6222 & 6222 & 6222 & 6222 & 6222 \\
\hline
\end{tabular}


TABLE 3: Explaining opinion formation and favouritism toward one institution

\begin{tabular}{|c|c|c|c|c|c|c|}
\hline & (1) & (2) & (3) & (4) & (5) & (6) \\
\hline & IMFMORE & BANKMORE & IMFMORE & BANKMORE & IMFOP & BANKOP \\
\hline \multirow[t]{2}{*}{ Age } & -0.000215 & $-0.00126 * *$ & 0.000621 & -0.000621 & 0.000287 & -0.000190 \\
\hline & $(0.000546)$ & $(0.000546)$ & $(0.000913)$ & $(0.000913)$ & $(0.000571)$ & $(0.000486)$ \\
\hline \multirow[t]{2}{*}{ Female Dummy } & $0.0300 * *$ & -0.0142 & $0.0469 * *$ & $-0.0469 * *$ & $-0.101 * * *$ & $-0.106^{* * *}$ \\
\hline & $(0.0117)$ & $(0.0154)$ & $(0.0207)$ & $(0.0207)$ & $(0.0150)$ & $(0.0144)$ \\
\hline \multirow[t]{2}{*}{ Urban Dummy } & -0.0137 & 0.0213 & -0.0270 & 0.0270 & $0.0798 * * *$ & $0.102 * * *$ \\
\hline & $(0.0135)$ & $(0.0185)$ & $(0.0257)$ & $(0.0257)$ & $(0.0207)$ & $(0.0205)$ \\
\hline \multirow[t]{2}{*}{ Unemployed Dummy } & 0.00306 & -0.00357 & 0.00673 & -0.00673 & 0.0172 & $0.0261^{*}$ \\
\hline & $(0.0149)$ & $(0.0165)$ & $(0.0225)$ & $(0.0225)$ & $(0.0141)$ & $(0.0142)$ \\
\hline \multirow[t]{2}{*}{ Health (0-6 scale) } & $0.00775^{* *}$ & $0.0114 * *$ & -0.000286 & 0.000286 & 0.00391 & 0.00297 \\
\hline & $(0.00393)$ & $(0.00529)$ & $(0.00704)$ & $(0.00704)$ & $(0.00638)$ & $(0.00571)$ \\
\hline Primary or Some Secondary Education & 0.0115 & 0.00873 & 0.00454 & -0.00454 & $0.217 * * *$ & $0.194 * * *$ \\
\hline (relative to Less than full primary) & $(0.0158)$ & $(0.0186)$ & $(0.0265)$ & $(0.0265)$ & $(0.0224)$ & $(0.0204)$ \\
\hline Secondary Education & 0.0163 & 0.0318 & -0.00547 & 0.00547 & $0.288 * * *$ & $0.245^{* * *}$ \\
\hline (relative to Less than full primary) & $(0.0169)$ & $(0.0244)$ & $(0.0287)$ & $(0.0287)$ & $(0.0292)$ & $(0.0261)$ \\
\hline Post Secondary & 0.0196 & -0.0220 & 0.0411 & -0.0411 & $0.355^{* * *}$ & $0.305^{* * *}$ \\
\hline (relative to Less than full primary) & $(0.0189)$ & $(0.0241)$ & $(0.0315)$ & $(0.0315)$ & $(0.0270)$ & $(0.0208)$ \\
\hline University Complete or Postgrad & -0.0144 & -0.0474 & 0.0115 & -0.0115 & $0.366^{* * *}$ & $0.303 * * *$ \\
\hline (relative to Less than full primary) & $(0.0268)$ & $(0.0441)$ & $(0.0578)$ & $(0.0578)$ & $(0.0331)$ & $(0.0312)$ \\
\hline \multirow[t]{2}{*}{ Poverty (0-24 Scale) } & 0.00124 & 0.00114 & 0.000953 & -0.000953 & $-0.00409^{*}$ & -0.00274 \\
\hline & $(0.00126)$ & $(0.00149)$ & $(0.00212)$ & $(0.00212)$ & $(0.00220)$ & $(0.00214)$ \\
\hline \multirow[t]{2}{*}{ Perception of Worse Relative Living Conditions } & 0.00585 & -0.00479 & 0.0125 & -0.0125 & $-0.0458 * * *$ & $-0.0510 * * *$ \\
\hline & $(0.0122)$ & $(0.0127)$ & $(0.0179)$ & $(0.0179)$ & $(0.0130)$ & $(0.0131)$ \\
\hline \multirow[t]{2}{*}{ Political Trust (0-21 Scale) } & 0.000803 & -0.00131 & 0.00224 & -0.00224 & -0.00107 & 0.000201 \\
\hline & $(0.00157)$ & $(0.00168)$ & $(0.00259)$ & $(0.00259)$ & $(0.00229)$ & $(0.00210)$ \\
\hline \multirow[t]{2}{*}{ Bribe Experience (0-15) } & -0.00235 & 0.00198 & -0.00537 & 0.00537 & $0.0246^{* * * *}$ & $0.0211 * * *$ \\
\hline & $(0.00268)$ & $(0.00381)$ & $(0.00521)$ & $(0.00521)$ & $(0.00435)$ & $(0.00416)$ \\
\hline Member of Community Development & -0.0136 & 0.00103 & -0.0167 & 0.0167 & $0.0676^{* * *}$ & $0.0784 * * *$ \\
\hline Association & $(0.0139)$ & $(0.0171)$ & $(0.0256)$ & $(0.0256)$ & $(0.0170)$ & $(0.0159)$ \\
\hline \multirow[t]{2}{*}{ Government Salary in Household } & 0.00493 & -0.00559 & 0.0161 & -0.0161 & $0.0457^{* * *}$ & $0.0468^{* * *}$ \\
\hline & $(0.0125)$ & $(0.0169)$ & $(0.0211)$ & $(0.0211)$ & $(0.0152)$ & $(0.0141)$ \\
\hline \multirow[t]{2}{*}{ Protectionist Dummy } & 0.000733 & 0.00966 & -0.0118 & 0.0118 & $0.0294 *$ & $0.0275^{*}$ \\
\hline & $(0.0137)$ & $(0.0140)$ & $(0.0189)$ & $(0.0189)$ & $(0.0170)$ & $(0.0146)$ \\
\hline Prefers Fewer Jobs with High Wages & -0.000804 & 0.0104 & -0.00612 & 0.00612 & $0.0492 *$ & 0.0325 \\
\hline
\end{tabular}


to More Jobs with Low Wages

Rating of Governments Efforts at Price Stability

Inequality OK Dummy

Abandon economic reforms vs. accept hardships

\section{Dummy}

Satisfied with government's reduced economic role

Dummy

Group Vs National Identity Dummy

Views Country's present economic condition

as Bad Dummy

Country's economic condition 12 months ago was

Worse Dummy

Pessimistic about Country's economic condition

in 12 months

\section{(0.0167)}

0.00705

$(0.0164)$

$-0.00850$

$(0.0115)$

0.0109

$(0.0132)$

0.0180

$(0.0111)$

0.00193

(0.0144)

$-0.0375^{* * *}$

(0.0135)

0.00339

$(0.0119)$

$0.0251 * *$

(0.0124)

5,552

$(0.0174)$
$-0.0407 * * *$
$(0.0146)$
0.00227
$(0.0159)$
0.000171
$(0.0145)$
-0.00197
$(0.0136)$
0.0114
$(0.0151)$
0.0000769
$(0.0154)$
-0.000583
$(0.0165)$
0.00216
$(0.0179)$
5.552

(0.0261)

0.0378

(0.0273)

$-0.0162$

$(0.0177)$

0.00912

$(0.0199)$

0.0199

$(0.0184)$

$-0.00488$

$(0.0213)$

$-0.0475^{*}$

$(0.0252)$

0.000940

$(0.0211)$

0.0311

(0.0204)

2,852

Standard Errors are clustered at the country and regional level and presented in

parenthesis. All specifications include country fixed effects. $* * * \mathrm{p}<0.01, * *$

$\mathrm{p}<0.05,{ }^{*} \mathrm{p}<0.1$ 


\section{TABLE A1: APPENDIX}

\begin{tabular}{|c|c|c|c|}
\hline Variable & Mean (S.D) & Obs. & Description \\
\hline IMF & $\begin{array}{l}6.31 \\
(2.62)\end{array}$ & 11020 & \multirow{2}{*}{$\begin{array}{l}\text { "Giving marks out of ten, where } 0 \text { is very badly and } 10 \text { is very well, } \\
\text { how well do you think the following institutions do their jobs?" }\end{array}$} \\
\hline World Bank & $\begin{array}{l}6.61 \\
(2.60)\end{array}$ & 12336 & \\
\hline Age & $\begin{array}{c}36.34 \\
(14.79)\end{array}$ & 22543 & "How old were you at your last birthday?" \\
\hline Female Dummy & $\begin{array}{l}0.49 \\
(0.50)\end{array}$ & 23165 & Equals 1 if the respondent is female \\
\hline Urban Dummy & $\begin{array}{l}0.37 \\
(0.48)\end{array}$ & 23165 & Equals 1 if the Primary Sampling Unit is urban \\
\hline Unemployed Dummy & $\begin{array}{l}0.25 \\
(0.43)\end{array}$ & 22982 & $\begin{array}{l}\text { Equals } 1 \text { if the respondent is unemployed. Derived from the question } \\
\text { "Do you have a job that pays a cash income? Is it full-time or part- } \\
\text { time? And are you presently looking for a job (even if you are } \\
\text { presently working)?" }\end{array}$ \\
\hline Health (0-6 scale) & $\begin{array}{l}1.74 \\
(1.59)\end{array}$ & 22800 & $\begin{array}{l}\text { Sum of two 0-3 scale indices of physical and mental health. Larger } \\
\text { numbers indicate worse health. See www.afrobarometer.org for } \\
\text { details of the individual questions }\end{array}$ \\
\hline Less than full primary & $\begin{array}{l}0.39 \\
(0.49)\end{array}$ & 23100 & \\
\hline Primary or Some Secondary Education & $\begin{array}{l}0.35 \\
(0.48)\end{array}$ & 23100 & \\
\hline Secondary Education & $\begin{array}{l}0.15 \\
(0.36)\end{array}$ & 23100 & "What is the highest level of education you have completed?" \\
\hline Post Secondary & $\begin{array}{l}0.09 \\
(0.28)\end{array}$ & 23100 & \\
\hline University Complete or Postgrad. & 0.02 & 23100 & \\
\hline
\end{tabular}


$(0.15)$

Poverty (0-24 Scale)

Perception of Worse Relative Living Conditions

(0.48)

Political Trust (0-21 Scale)

Bribe Experience (0-15 Scale)

Member of Community Development

Association

$(1.79)$

0.19

(0.39)

0.25

Protectionist Dummy

0.67

Prefers Fewer Jobs with High Wages

to More Jobs with Low Wages

0.34

$(0.47)$

0.38

$(0.49)$

Inequality OK Dummy
Government Salary in Household

Sum of 0-4 scale indices of shortages of food, water, medical care, electricity, fuel for cooking and cash income. Larger numbers indicate more poverty. See www.afrobarometer.org for details of the individual questions

Equals 1 if the respondent indicates that they rate their living conditions compared to those of other countrymen as worse and 0 if better or the same

18957 See Main Text

\section{See Main Text}

\section{See Main Text}

Equals 1 if the respondent is an official leader or an active member of community development or self-help association

"Do you or your household rely on the income of anyone who works for the government? Including anyone who works for local

government as well as central government or anyone who works as a teacher in a public school."

"Protect producers within our own country by imposing tariffs that make imported goods more expensive" over "import affordable goods from other countries, even if some of our own producers are forced out of business.'

"Better to have higher wages, even if this means that some people go without a job" over "better for everyone to have a job even if this means that average wages are low."

Takes a value of 1 if the respondent feels that the government is doing fairly well or very well at keeping prices stable and 0 if fairly badly or very badly.

Takes a value of 1 if the respondent agrees that "It is alright to have large differences of wealth because those who work hard deserve to be rewarded." 
Abandon economic reforms vs. accept hardships

Dummy

$(0.47)$

Satisfied with government's reduced economic role

0.47

Dummy

Group Vs National Identity Dummy

0.39

$(0.49)$

Views Country's present economic condition as Bad Dummy

0.50

$(0.50)$

Country's economic condition 12 months ago was

0.36

Worse Dummy

(0.48)

Pessimistic about Country's economic condition

in 12 months
"The costs of reforming the economy are too high; the government should therefore abandon its current economic policies" over "...for the economy to get better in the future, it is necessary for us to accept some hardships now.'

Equals 1 if the respondent answers satisfied or very satisfied to

"...the government has reduced its role in the economy. Overall, how satisfied are you with the way this policy works?" and 0 if they are dissatisfied.

Equals 1 if the respondent would identify more with their ethnic group rather than the national identity (if they had to choose).

Equals 1 if the respondent sees the country's present economic conditions as bad or very bad.

Equals 1 if the respondent sees the country's present economic conditions as worse compared to 12 months ago.

Equals 1 if the respondent thinks that the country's economic conditions will be worse in 12 months time. 